\title{
Impact of climate variability of the Western Tropical Pacific on maximum salinity water in the South China Sea
}

\author{
Joachim W. Dippner ${ }^{1} \cdot$ Sarah C. Weber ${ }^{1,2} \cdot$ Ajit Subramaniam $^{3}$
}

Received: 6 January 2021 / Accepted: 16 August 2021 / Published online: 31 August 2021

(c) The Author(s) 2021, corrected publication 2022

\begin{abstract}
Salinity observations in the Vietnamese upwelling area in June 2016 indicated a significant increase in the salinity of the maximum salinity water (MSW). The source of MSW inflow into the South China Sea (SCS) is a mixture of the Western North Pacific Central Water and the North Pacific Equatorial Water. Although the East Asian winter monsoon is correlated with both the El Niño Southern Oscillation (ENSO) and the Pacific Decadal Oscillation (PDO), the mean salinity of MSW is only spuriously lag correlated to the PDO, but highly correlated to all tropical climate modes (except El Niño Modoki) with a time lag up to 7 months. Composite analyses indicate that the modulation of ENSO by a PDO in a positive phase results in optimal inflow conditions. A comparison of two post-El Niño years with different PDO polarity (negative in 2003 and positive in 2016) shows that the dominant driver is the variability in outgoing long-wave radiation (OLR) and in zonal wind in the tropics. In 2003, enhanced convective activity over the West Pacific warm pool resulted in a cyclonic circulation. In 2016, convective activity was weak and an anticyclonic circulation was intensified, which transported the saltier North Pacific Equatorial Water into the SCS. This observed increase in the salinity of MSW requires a modification of the previous definitions of characteristic water masses, which is presented here. The question of whether or not the increase in MSW salinity is a transient phenomenon cannot be answered. It might be possible that the increase in salinity is related to global warming.
\end{abstract}

Keywords ENSO $\cdot$ PDO $\cdot$ East Asian monsoon $\cdot$ Water mass analysis $\cdot$ South China Sea $\cdot$ Western Tropical Pacific

\section{Introduction}

The Luzon Strait Transport (LST) is a part of the South China Sea throughflow (SCSTF), which is an important conveyor belt between the Pacific and Indian Oceans $(\mathrm{Qu}$ et al. 2006). The LST is driven by two different water masses entering the South China Sea (SCS) through Luzon Strait: the Western North Pacific Central Water (WNPCW) and the North Pacific Equatorial Water (NPEW, Figs. 1 and 2). Both water masses have distinct salinities (Tomczak and Godfrey 1994) and form the maximum salinity water (MSW), which

Communicated by Responsible Editor: Aida Alvera-Azcárate.

Joachim W. Dippner

dippner@io-warnemuende.de

1 Leibniz Institute for Baltic Sea Research Warnemünde, Seestr. 15, 18119 Rostock, Germany

2 University of Southern Denmark, Odense, Denmark

3 Lamont Doherty Earth Observatory, Columbia University, Palisades, NY, USA is a characteristic water mass in the SCS (Rojana-Anawat et al. 2001) and the core water of the seasonal upwelling off the Vietnamese coast (Dippner et al. 2007). Rojana-Anawat et al. (2001) have previously identified seven characteristic water masses in the western SCS, which were later improved by Dippner and Loick-Wilde 2011. Recent observations in the upwelling area of SCS (Fig. 2) by the "RV Falkor" in June 2016 indicated a statistically significant increase in the salinity of MSW. The consequence was that a subset of the hydrographic observations did not fit into the definition of characteristic water masses given by Dippner and Loick-Wilde (2011). As such, the water mass definition needs a modification, which is presented here. The scientific questions considered here are why did the MSW salinity increase and what is the mechanism behind this phenomenon?

The circulation in the SCS (e.g., Dale 1956; Wyrtki 1961; Pohlmann 1987; Metzger and Hurlburt 1996) is forced by a spatial homogeneous northeast monsoon (NEM), during winter and by the curl of the wind stress during the southwest monsoon (SWM) in summer (Chao et al. 1996). The 


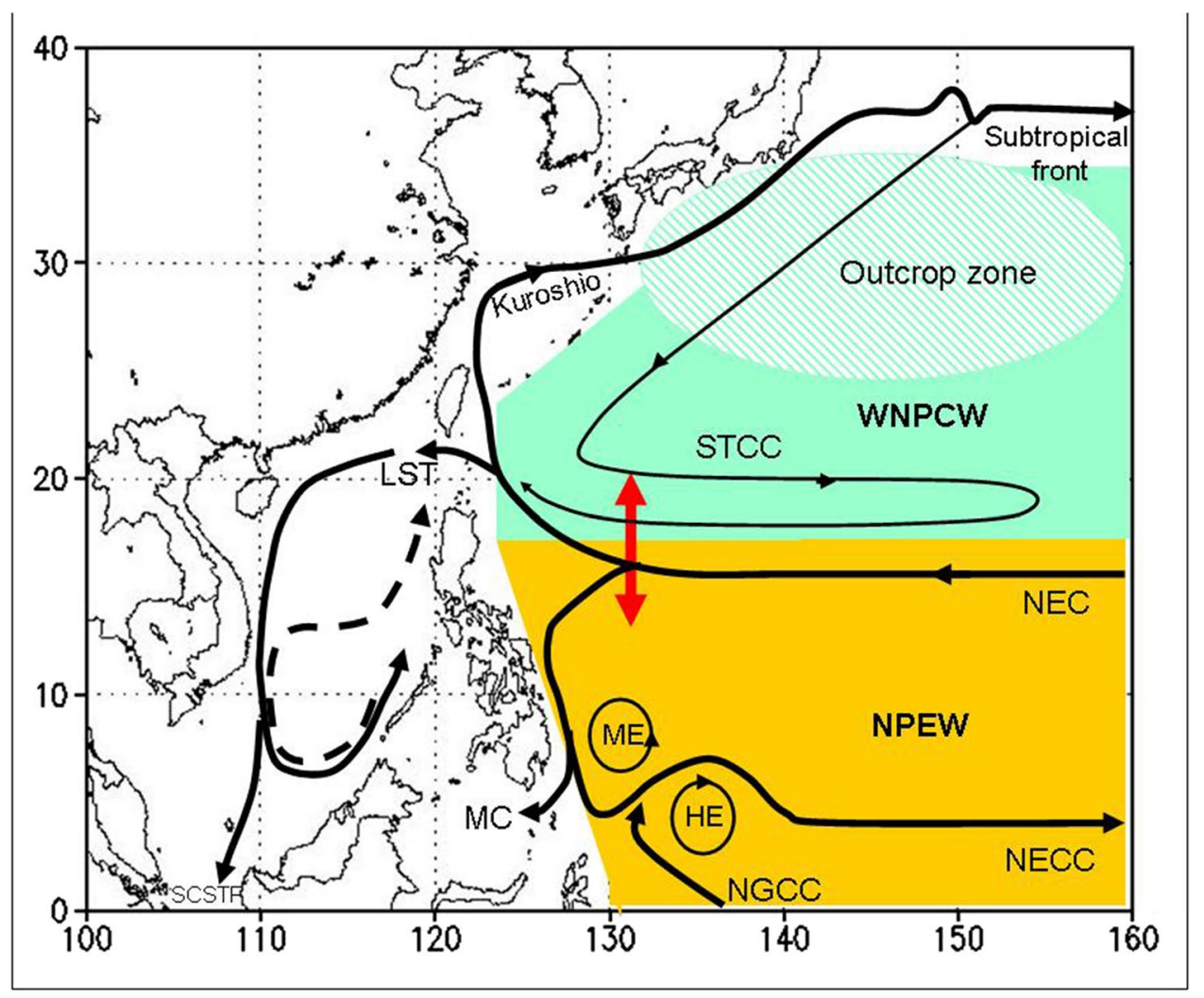

Fig. 1 Water masses and mean circulation in the western North Pacific. The acronyms for the water masses are as follows: Western North Pacific Central Water (WNPCW) and North Pacific Equatorial Water (NPEW), and the circulation system: North Equatorial Current (NEC), North Equatorial Counter Current (NECC), Subtropical Counter Current (STCC), New Guinea Coastal Current (NGCC), Mindanao Current (MC), Luzon Strait Transport (LST), Mindanao eddy (ME), and Halmahera eddy (HE). The figure is compiled using

circulation in the southern SCS (Fig. 1) is characterized by a cyclonic gyre during winter and an anticyclonic gyre during summer. In the northern part of the SCS, the circulation is forced by the monsoon and the LST (Hu et al. 2000) forming a basin wide cyclonic gyre in the SCS during winter. In summer (dashed line in Fig. 1), both gyres form a dipole circulation cell causing an offshore current off the coast of Vietnam at $\sim 12^{\circ} \mathrm{N}$ (Dippner et al. 2007).

The LST, which represents the leaking path of the Kuroshio intrusion into SCS (Sheremet 2001; Nan et al. 2015), occurs all year round with a pronounced semiannual signal, with greater strength during winter and summer monsoon and weaker strength during inter-monsoon (Qu et al. 2000). A process analysis indicates that $\sim 95 \%$ of the salinity variability in the LST is caused by advection due to the Kuroshio intrusion; the impact of river discharge and the air-sea freshwater flux are much smaller (Nan et al. 2016). Hence, the reason for the variability of salinity is located in the dynamically complex Western Tropical Pacific (WTP; Qu et al. water mass distributions and circulation fields of Tomczak and Godfrey (1994) and Kashino et al. (2013). The circulation field and the position of the "outcrop zone" were adapted from Yan et al. (2013). According to Kim et al. (2004), the red arrow marks the variability in bifurcation latitude of the NEC. The schematic surface circulation in the SCS was adopted from Liu et al., (2002): winter circulation (full line), summer circulation (dashed line)

2004; Yan et al. 2013; Nan et al. 2015 and references therein; Kidwell et al. 2017; Hu et al. 2017; Roxy et al. 2019).

Besides the seasonal variability, the dynamics of WTP and adjacent seas are driven by different multi-time scale processes. On an intra-annual time scale, two frequency bands exist: the quasi biweekly (12-25 days) time scale (Chen and Chen 1995) and the 30-60-day tropical Madden and Julian $(1972,1994)$ Oscillation (MJO), which is a climate mode influenced by the outgoing long-wave radiation (OLR) and the atmospheric circulation in the tropics (Wang et al. 2009). On the inter-annual time scale, the variability of monsoon intensity is influenced by ENSO events and the position of the Inter-Tropical Convergence Zone (Dippner et al. 2013). On inter-decadal scales, the variability of circulation is forced by the PDO (Qu et al. 2005), by the Tropical Pacific Decadal Variability (TPDV; Tourre et al. 2001) and by the variability of the WTP warm pool.

The Pacific North Equatorial Current (NEC), located between the subtropical and tropical gyre, bifurcates west of 


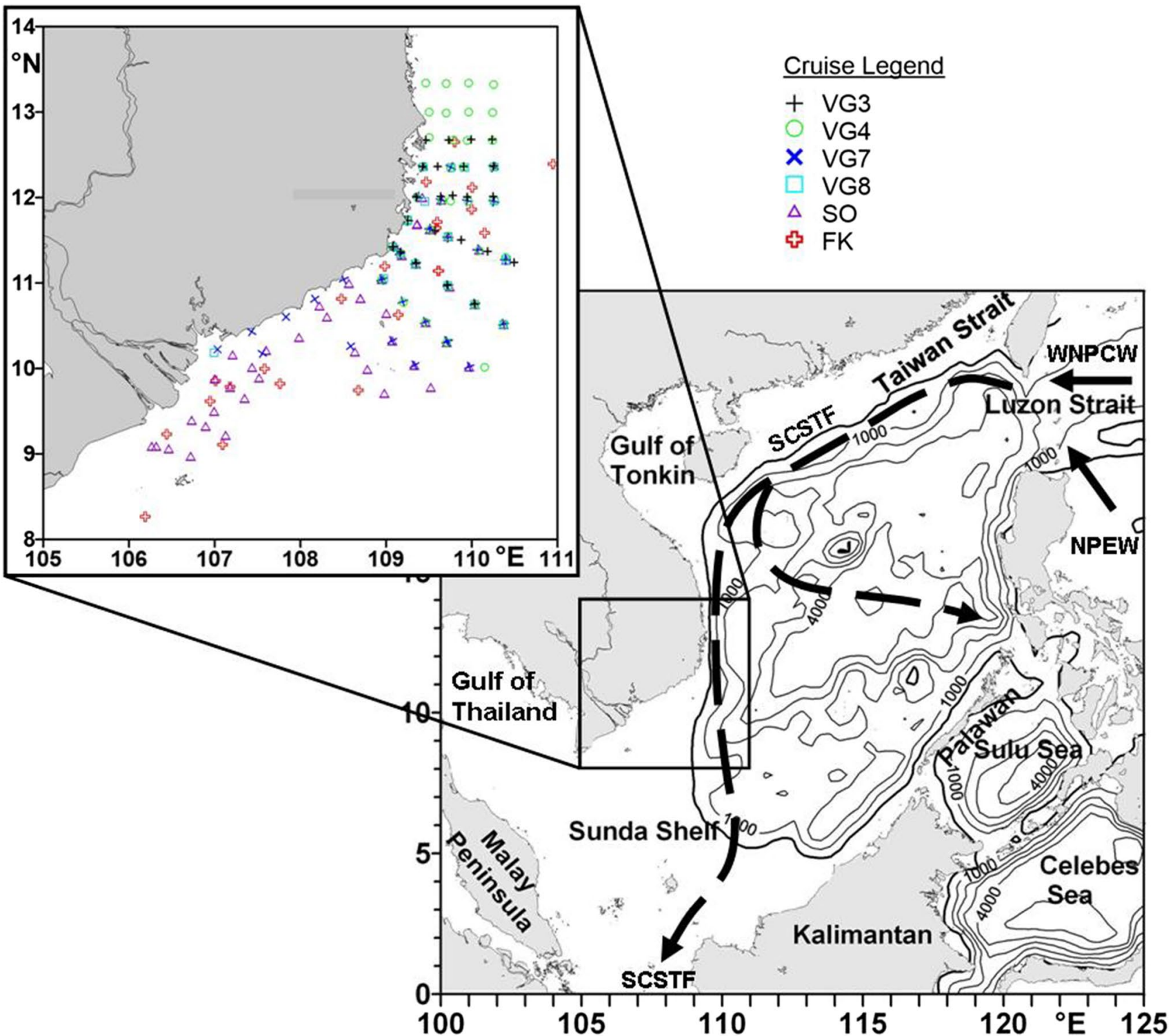

Fig. 2 Map and topography of the South China Sea. The contour interval is $1000 \mathrm{~m}$, and the shelf edge (200-m contour line) is marked by a bold line. The dashed arrows indicate qualitatively the SCSTF, the sources of which are WNPCW and NPEW. The rectangle marks

the Philippines into the northward Kuroshio and the southward Mindanao Current (Fig. 1; Qu et al. 2009; Tozuka et al. 2009; Yan et al. 2013). The latitude of NEC bifurcation is mainly related to ENSO on an inter-annual time scale (Zhai et al. 2014), whereas the decadal variation is highly positively correlated with the TPDV (Tourre et al. 2001). The bifurcation occurs at $\sim 15.5^{\circ} \mathrm{N}$ on annual average with a band width of fluctuation in bifurcation latitude from $13^{\circ} \mathrm{N}$ near the surface to $20^{\circ} \mathrm{N}$ at $800-\mathrm{m}$ water depth (Kim et al. 2004), whereas $\mathrm{Hu}$ et al. (2015) gave a band width in bifurcation latitude from $13^{\circ} \mathrm{N}$ to $17^{\circ} \mathrm{N}$. The depth of the subsurface salinity maximum (120-150 m) in the WTP is shallower in the area of investigation. The inlay shows the stations of the different cruises in the Vietnamese upwelling area: VG-3 (black+), VG-4 (green $\bigcirc$ ), VG-7 (blue $\mathrm{x}$ ), VG-8 (cyan $\square$ ), SO-187-2 (violet $\Delta$ ), and FK160603 (red 卢)

the northern basin and deeper in the southern basin (Zeng et al. 2016). During El Niño years, the NEC bifurcation generally occurs at northern latitudes (Kim et al. 2004), resulting in a weaker Kuroshio and a favorable inflow condition of NPEW (Chu and Li 2000; Qu et al. 2005; Zhai et al. 2014).

Based on satellite data and in situ observations, the LST shows a pronounced decadal variation in subsurface salinity (Zeng et al. 2016) with periods of freshening between 1990 and 2012 (Zeng et al. 2014; Nan et al. 2016) and an ongoing period of salinification since 2012 (Zeng et al. 2018). However, no consensus exists on the mechanisms behind this phenomenon. Various authors addressed LST variability 
to ENSO (Zhai et al. 2014; Qu et al. 2004) whereas others pointed to PDO (Zeng et al. 2018; 2016; 2014). Yet another group applied the Island Rule (Godfrey 1989) and concluded that wind stress over the whole equatorial Pacific is the key factor regulating the inter-annual variability of the LST (Wang et al. 2006; Yu and Qu 2013).

Both climate modes, ENSO and PDO, have a similar impact on the Pacific Ocean (Mantua 2001); therefore, separating the dynamic when both modes are in the same phase is difficult. Decadal variations in the sea surface salinity, precipitation, and horizontal and vertical advection during El Niño (La Niña) events show remarkable similarities with those occurring during the positive (negative) phases of the PDO (Delcroix et al. 2007). Evidence also exists that lowfrequency climate fluctuation of PDO modulates El Niño intensity (Gershunov and Barnett 1998; Barnett et al. 1999; Torrence and Webster 1999; Tourre et al. 2001; 2005). In addition, it is also not trivial to separate the dynamic of PDO and TPDV because different lead-lag correlations indicated high correlations between PDO and TPDV (Zhai et al. 2014).

The SCS is located between the four monsoon subsystems: the subtropical East Asian monsoon (EAM), the tropical Indian monsoon, the tropical western North Pacific monsoon, and the Australian monsoon (Wang et al. 2009). Unfortunately, more than 20 definitions exist for EAM (Wang and Fan 1999; Chen et al. 2000, 2013; Huang et al. 2003; Wang et al. 2004 and references therein). Wang et al. (2004) pointed out that all definitions vary with respect to the considered variables, including pressure levels, seasons, periods, areas, and data sets. The consequence is that no consistent definition of EAM exists, which may contribute to the variety on LST variability.

This study asks the following scientific questions: what drives this increase in MSW salinity and is it a transient phenomenon? To address these questions, we compute lag correlations between the MSW salinity and different climate modes, and we present surface geostrophic current products from satellite for selected periods (QUID 2018). We additionally use National Center of Environmental Prediction/ National Center of Atmospheric Research (NCEP/NCAR) reanalysis data (Kalnay et al. 1996) to construct various composites and an EAM winter index (EAWMI) to analyze the potential reasons for the increase in MSW salinity and the role of different climate time series in influencing its inter-annual variability.

\section{Material and methods}

Six cruises were conducted on the Vietnamese shelf in the SCS $\left(8^{\circ}-14^{\circ} \mathrm{N}\right.$ and $\left.105^{\circ}-111^{\circ} \mathrm{E}\right)$ in an effort to characterize the local water masses and seasonal upwelling region (Fig. 2). Five of the six cruises took place between July 2003 and April 2006 aboard the "MV Nghien Cuu Bien" and "RV Sonne," whereas the sixth occurred in June 2016 aboard the "RV Falkor." In total, the expeditions covered a range of different seasonal monsoon conditions, as well as post-El Niño climatic conditions in 2003 and 2016 (Table 1). SeaBird Scientific CTD systems were used on all cruises with calibrated sensors. Data were validated using a salinometer. The TS-diagram and the mean MSW salinity of all casts and cruises are shown in Fig. 3 and Fig. S1 in the Supplementary Information (SI).

Monthly mean values of the PDO index, the Niño3.4 index, the Multivariate ENSO Index (MEI), the TPDV index, and the El Niño Modoki index (EMI) were used to determine the influence of the WTP variability on LST. The PDO index (Hare and Mantua 2000; Mantua and Hare 2002) is derived as the leading empirical orthogonal function (EOF) of monthly sea surface temperature anomalies (SSTA) in the North Pacific Ocean, poleward of $20^{\circ} \mathrm{N}$. The Niño3.4 index is the area averaged monthly SSTA from $5^{\circ} \mathrm{S}-5^{\circ} \mathrm{N}$ and $170^{\circ}-120^{\circ} \mathrm{W}$ calculated from the HadlSST 1 dataset (Rayner et al. 2003). The MEI is based on six primary variables observed over the tropical Pacific: sea-level pressure (SLP), zonal and meridional components of the surface wind, SST, surface air temperature, and total cloudiness fraction of the sky. The MEI is calculated as the first unrotated EOF of all six observed fields combined (Wolter 1987). The TPDV index is defined as the time coefficients of the first EOF mode of the decadal SSTA in the tropical Pacific Ocean between $120^{\circ}-280^{\circ} \mathrm{E}$ and $25^{\circ} \mathrm{S}-25^{\circ} \mathrm{N}$ (Zhai et al. 2014). Unfortunately, this time series is in the NCEP/
Table 1 Ship and cruise name, sampling dates, season/ climatic period, and number of stations and CTD casts. Southwest monsoon (SWM), inter-monsoon (IM), northeast monsoon (NEM)

\begin{tabular}{llllll}
\hline Ship & Cruise & Cruise date & Season/climactic period & No. of stations & No. of CTDs \\
\hline MV Nghien Cuu Bien & VG-3 & July 2003 & SWM, post-ENSO & 38 & 74 \\
MV Nghien Cuu Bien & VG-4 & April 2004 & Spring IM & 38 & 71 \\
MV Nghien Cuu Bien & VG-7 & July 2004 & SWM & 34 & 45 \\
MV Nghien Cuu Bien & VG-8 & March 2005 & NEM (decaying) & 22 & 41 \\
RV Sonne & SO-187-2 & April 2006 & Spring IM & 68 & 100 \\
RV Falkor & FK160603 & June 2016 & SWM, post-ENSO & 23 & 55 \\
Total & & & & $\mathbf{2 2 3}$ & $\mathbf{3 8 6}$ \\
\hline
\end{tabular}



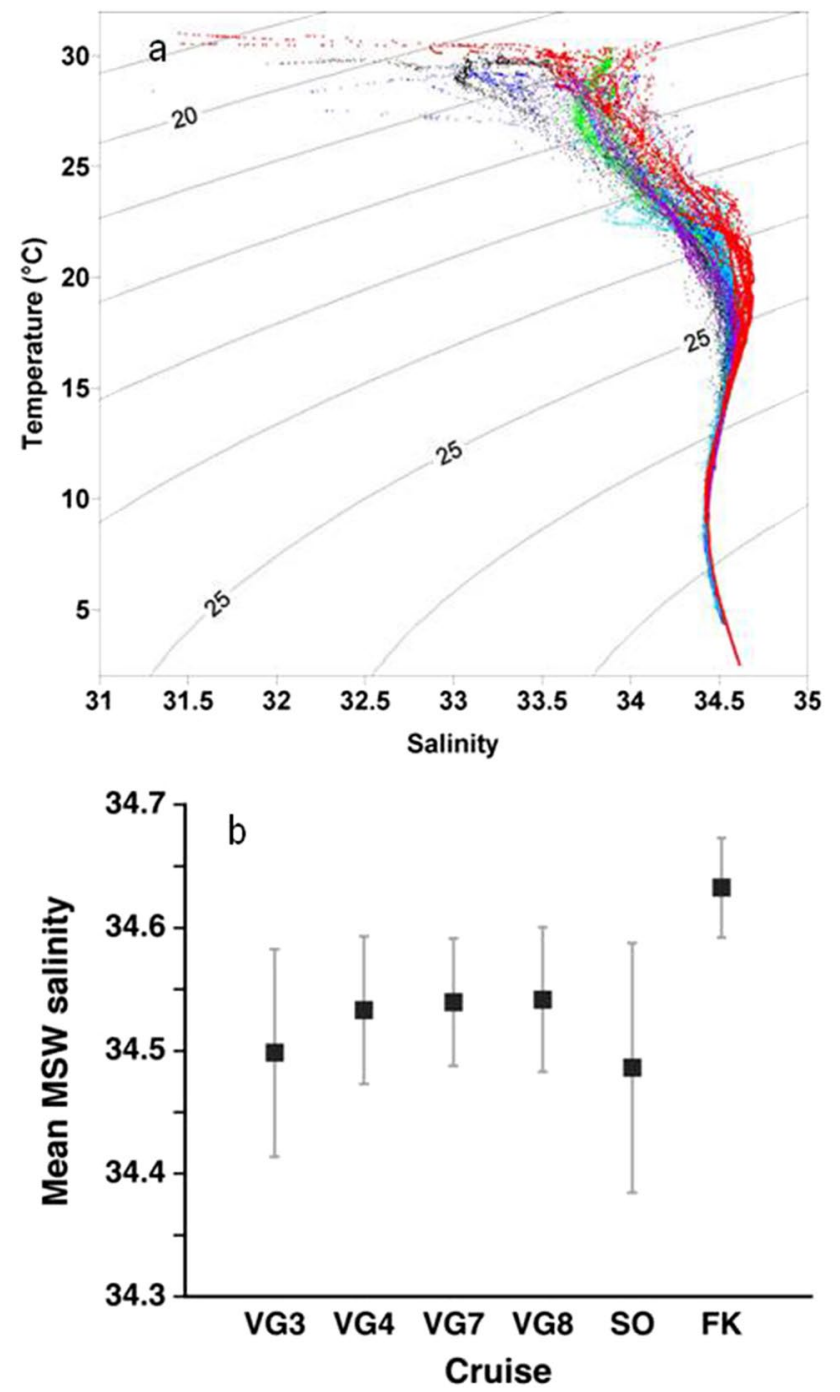

Fig. 3 a TS-diagram for all cruises in the Vietnamese upwelling area. The color code of the cruises is given in Fig. 2. The isolines mark the density in $\sigma_{t}$ units. b Mean and standard deviation of MSW salinity for the different cruises. The mean salinity value of MSW is based on 1937 observations during VG3, 2546 during VG4, 2144 during VG7, 2178 during VG8, 1905 during SO, and 2395 during FK. Further details of the cruises are provided in Table 1

NCAR reanalysis only available until 2008. Therefore, we define here the TPDV index as the mean decadal STTA over the same region. EMI as an index of intensity of the central Pacific El Niño is computed using the tripolar procedure of Ashok et al. (2007): EMI $=[\mathrm{SSTA}]_{\mathrm{A}}-0.5 *[\mathrm{SSTA}]_{\mathrm{B}}-0.5 *[\mathrm{~S}$ STA $]_{C}$. The brackets represent the area-averaged SSTA in the region $\mathrm{A}\left(165^{\circ} \mathrm{E}-140^{\circ} \mathrm{W}, 10^{\circ} \mathrm{S}-10^{\circ} \mathrm{N}\right), \mathrm{B}\left(110^{\circ}-70^{\circ} \mathrm{W}\right.$, $\left.15^{\circ} \mathrm{S}-5^{\circ} \mathrm{N}\right)$, and $\mathrm{C}\left(125^{\circ}-145^{\circ} \mathrm{E}, 10^{\circ} \mathrm{S}-20^{\circ} \mathrm{N}\right)$. These climate modes on a monthly base and their lag correlation to the monthly MSW salinity are displayed in Fig. 4.

NCEP/NCAR reanalysis data (Kalnay et al. 1996) were used to construct an EAM winter index (EAWMI) and composites of geo-potential height (GPH) anomalies and vector wind anomalies at the $850 \mathrm{hPa}$ level for SWM (May to September) and NEM (November to February). We analyzed winter as well as summer composites because the LST has the strongest signals during these periods ( $\mathrm{Qu}$ et al. 2000).

We selected the area $0^{\circ}-40^{\circ} \mathrm{N}$ and $100^{\circ}-160^{\circ} \mathrm{E}$ for the following reasons (Fig. 1): it encompasses the area affected by the EAM, including the SCS $\left(10^{\circ}-25^{\circ} \mathrm{N}, 110^{\circ}-130^{\circ} \mathrm{E}\right)$ and the East China Sea $\left(25^{\circ}-40^{\circ} \mathrm{N}, 120^{\circ}-140^{\circ} \mathrm{N}\right.$; Chen et al. 2000); it covers the area of the western North Pacific monsoon $\left(5^{\circ}-22.5^{\circ} \mathrm{N}, 105^{\circ}-150^{\circ} \mathrm{E}\right.$; Wang et al. 2009$)$, the western Pacific subtropical high, and the northern hemisphere part of the WTP warm pool (Huang et al. 2003) and its split region between NEC and NECC (Hu et al. 2017). The area also covers the so-called outcrop zone $\left(25^{\circ}-35^{\circ} \mathrm{N}\right.$, $130^{\circ}-160^{\circ} \mathrm{E}$ ) where a subsurface salinity anomaly propagates southwestward to the east of Luzon Strait (Yan et al. 2013). The eastward extension of the area is $160^{\circ} \mathrm{E}$, which is approximately the position of the nodal line between the area of positive and negative anomalies of the Southern Oscillation (Bjerknes 1969).

Following Chen et al. (2013), we constructed the winter (December, January, and February; DJF) monsoon index as follows. We used NCEP/NCAR reanalysis data (Kalnay et al. 1996) of the meridional wind speed anomalies at $850 \mathrm{hPa}$ level averaged over the areas influenced by the EAM, the SCS, and the East China Sea. The meridional component was used because it has a higher variability than the zonal wind component (Huang et al. 2003). Similar to Chen et al. (2013), we separated the EAWMI time series into ENSOrelated and ENSO-unrelated parts. The ENSO-related part was calculated by a linear regression of the time series with respect to the winter MEI. The ENSO-unrelated part is the residuum between the total index and its ENSO-related part, which was then correlated to the winter PDO (Fig. 5).

The composites of GPH and vector winds at the $850 \mathrm{hPa}$ level (Fig. 6 and Figs. S2-S9) in SI were constructed for years with extreme PDO and ENSO values. PDO + values occurred in 1959, 1967, 1986, 1995, and 2004 and PDO - values in 1955, 1963, 1972, 1991, and 2000 (Chan and Zhou 2005; Chen et al. 2013; Yu and Qu 2013). ENSO + values occurred in 1973, 1983, 1992, 1998, 2010, and 2016, whereas ENSO - values occurred in 1956, 1974, 1976, 1989, 2000, and 2011. Furthermore, we constructed composites with respect to the polarity of PDO. Table 2 displays the considered years. According to Gershunov and Barnett (1998), extreme ENSO events were conservatively defined to occur when DJF mean values of both the Niño3.4 and MEI indices deviate more than 0.8 standard deviations from the long-term mean. The ENSO + and ENSO - events were related to the positive and negative phases of PDO. During the period from 1948 to 2017, different PDO epochs were identified: 1947-1976 was a PDO - phase, followed by 
Fig. 4 a Time series of standardized monthly values of PDO, MEI, Niño3.4 index, TPDV index, and EMI. The time series were low-pass filtered with a cutoff period of 25 months. b Correlation coefficients between monthly mean MSW salinity and PDO, MEI, Niño3.4, TPDV index, and EMI for different time lags. The long and short dashed black lines are the $95 \%$ and $99 \%$ confidence levels, respectively
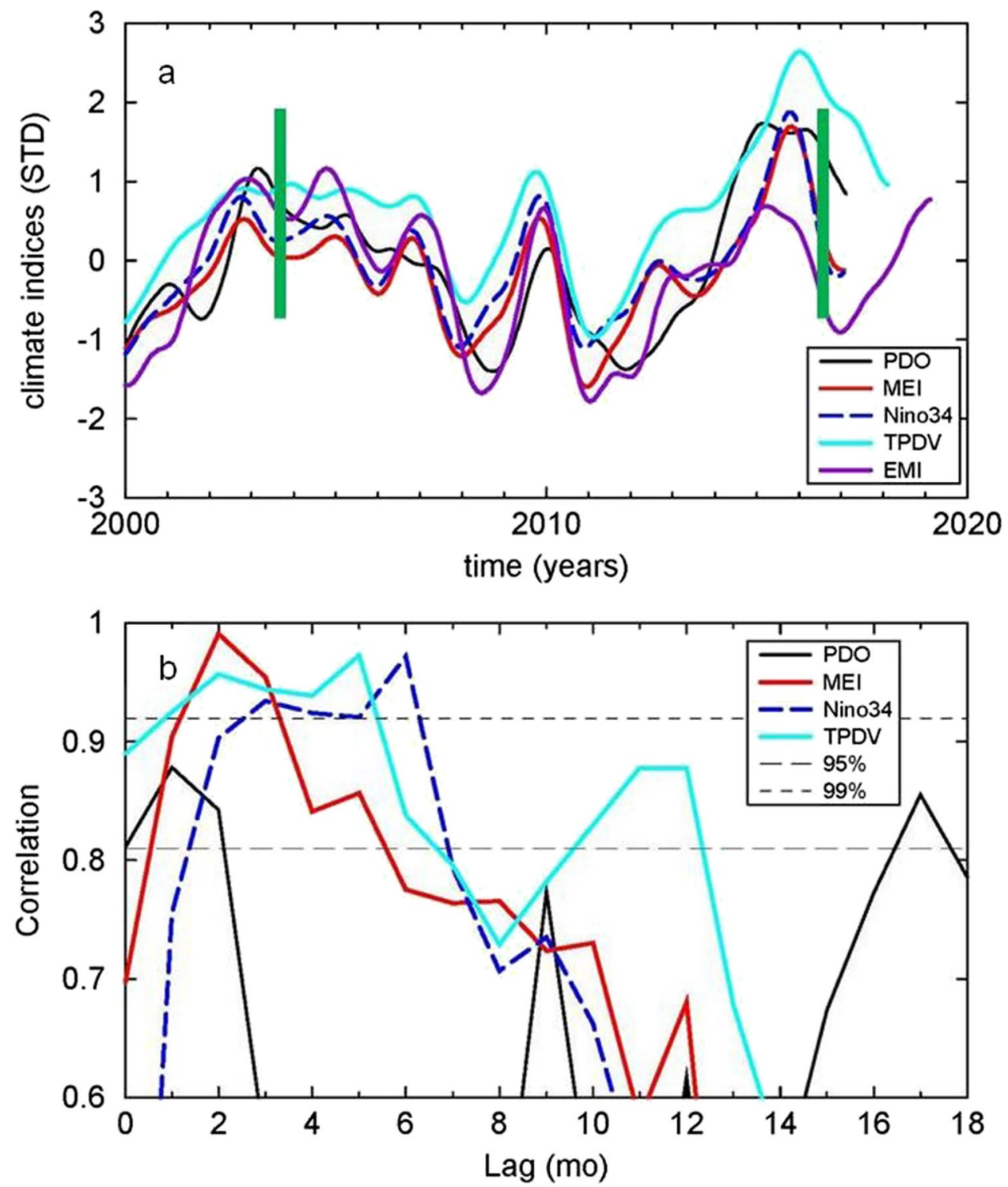

a 1977-1993 PDO + phase (Gershunov and Barnett 1998), a 1993-2012 PDO - phase (Nan et al. 2016; Zeng et al. 2016), and a PDO + phase from 2012 up to today (Zeng et al. 2018). These classifications of the PDO polarity are a result of decadal filtering and therefore not visible in our monthly data (Fig. 4a).

To understand the complex dynamics of WTP and the difference between the post-ENSO + years 2003 and 2016, we investigated surface velocities, MJO time series, and spatial structure of OLR anomalies and $850 \mathrm{hPa}$ vector wind anomalies for the specific years. Daily gridded surface geostrophic velocities were obtained from the EU Copernicus Marine Service Global Ocean Gridded L4 Sea Surface Heights Product (QUID 2018). This product is produced by the SL-TAC multi-mission altimeter data processing system using data from all altimeter missions: Jason-3, Sentinel-3A, HY-2A, Saral/AltiKa, Cryosat-2,
Jason-2, Jason-1, T/P, ENVISAT, GFO, ERS1/2. The geostrophic current products were computed using a 9-point stencil width method (Arbic et al. 2012) for latitudes outside of $\mathrm{a} \pm 5^{\circ}$ band. In the equatorial band, the Lagerloef method introducing the $\beta$-plane approximation was used (Lagerloef et al. 1999). Details on the procedure, including how the products were processed, are given in Pujol et al. (2016). The daily velocity fields, which have a spatial resolution of $0.25^{\circ}$, were extracted and averaged for winter (DJF) monsoon and the onset of summer monsoon (MJJ) in early summer for 2003 and 2016 (Fig. 7).

In addition, to understand the difference between 2003 and 2016, we construct fields for winter (DJF) and early summer (MJJ) anomalies of surface OLR (Fig. 8) and vector wind at $850 \mathrm{hPa}$ (Fig. 9) using NCEP/NCAR reanalysis data (Kalnay et al. 1996). 
Fig. 5 a East Asian winter monsoon index (EAWMI); b ENSOrelated part of the EAWMI (red line), black bars mark the winter MEI; c ENSO-unrelated part of the EAWMI (red line), black bars mark winter PDO index. Both curves are significantly correlated $(r=-0.36, p<0.05$, $N=68)$
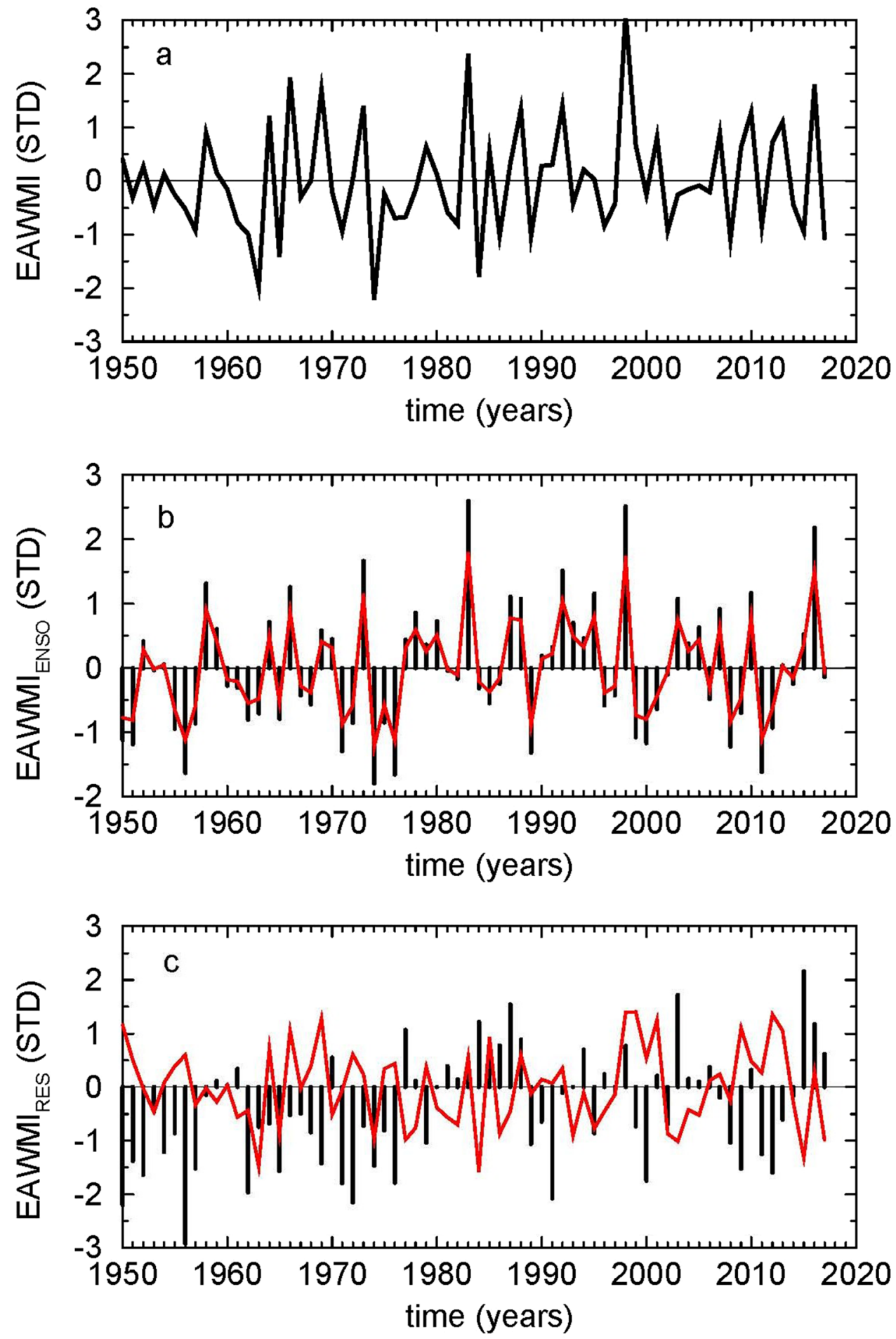

\section{Results}

The TS-diagram (Fig. 3, Fig. S1 in SI) shows a much higher salinity in waters encountered during the 2016 "RV Falkor" cruise compared to those in the previous cruises. This increase is especially pronounced in the mean salinity of MSW (Fig. 3), which is the core water of the Vietnamese coastal upwelling. The broadening of the MSW salinity range in the TS-diagram between the 24 and 25 isopycnals of $\sigma_{t}$ densities represents variability in the water mass, which can be attributed to the mechanism of differential mixing of its source waters (Siedler 1970), NPEW and WNPCW. Observations (Tomczak and Godfrey 1994) indicate that NPEW has a core salinity $S>34.55$ and for the 
Fig. 6 Composites of GPH anomalies and vector winds at the $850 \mathrm{hPa}$ level during southeast monsoon for ENSO + and different PDO polarity $(\mathrm{ENSO}+\mathrm{PDO}+)$ and $(\mathrm{ENSO}+\mathrm{PDO}-)$. The contour interval is $1 \mathrm{~m}$
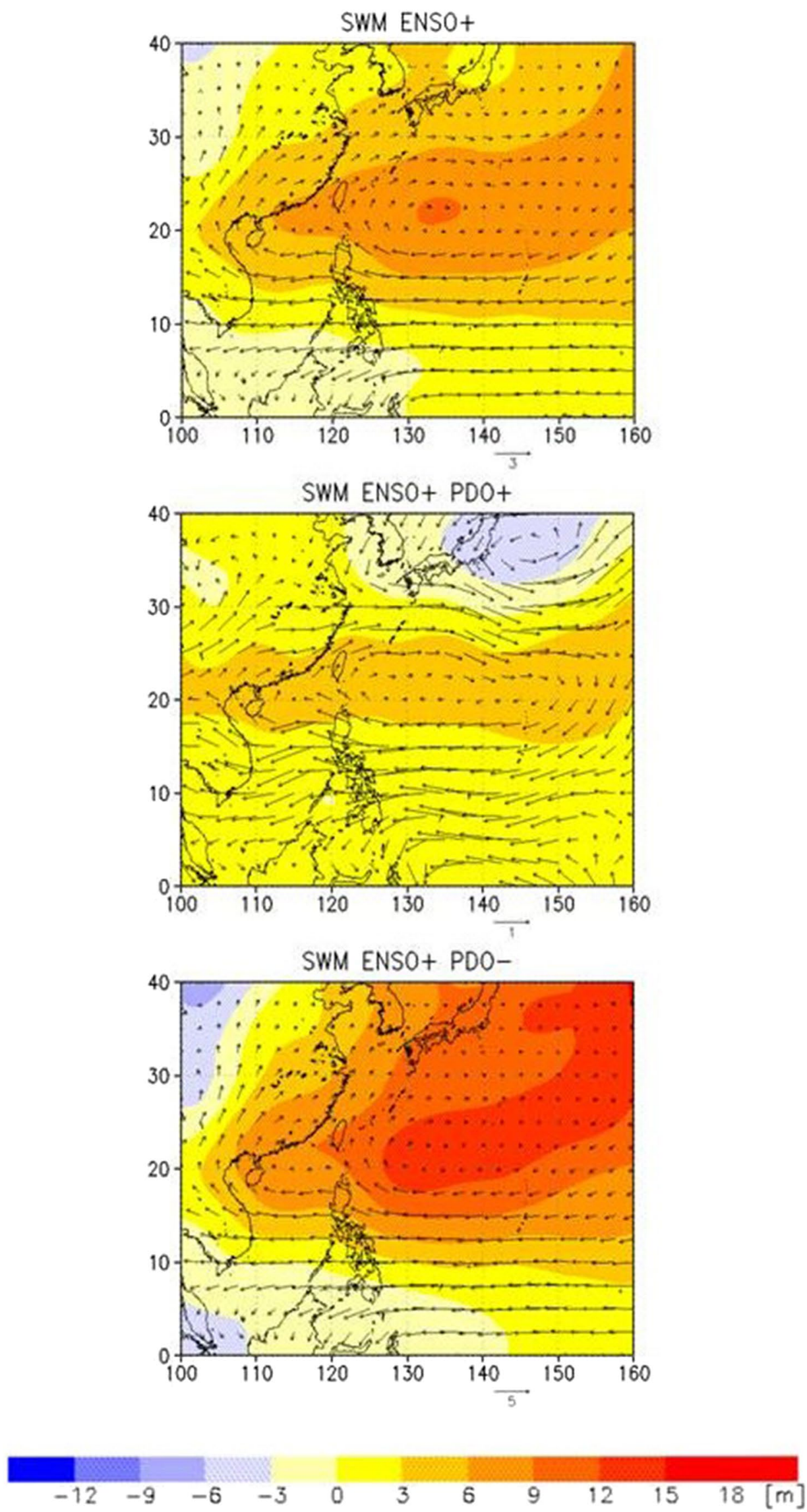
Table 2 Classification of phases of ENSO and PDO for composite construction

\begin{tabular}{lll}
\hline & PDO + & PDO - \\
\hline ENSO + & $1983,1992,2016$ & $1973,1998,2010$ \\
ENSO - & 1985,1989 & 1956,1974, \\
& & 1976,2000, \\
& & 2011 \\
\hline
\end{tabular}

same water mass, Qu et al. (1999) gave a band width of $34.75<S<35.25$. In contrast, WNPCW has a core salinity of $S<34.4$ (Tomczak and Godfrey 1994). The absolute values of mean MSW salinity are thus remarkable: in 2016, the mean value was 34.63 , allowing for the conclusion that the LST consisted only of NPEW. The mean MSW salinity was 34.5 between 2003 and 2006, which might indicate a specific amount of mixing between WNPCW and NPEW east of Luzon. This is supported by the salinity budget of Zeng et al. (2016) who suggested that entrainment from the mixed layer played a more important role in the freshening period than in the salinifying period.

The LST propagates from the Luzon Strait along the shelf edge of the SCS $1970 \mathrm{~km}$ to reach the center of the upwelling at $12^{\circ} \mathrm{N}$, where its signal can be detected in MSW.
This means that after passing the Luzon Strait, the LST and later the SCSTF reaches the Vietnamese upwelling area 2 to 3 months later, which requires mean travelling speeds of $\sim 0.38 \mathrm{~m} / \mathrm{s}$ and $\sim 0.25 \mathrm{~m} / \mathrm{s}$, respectively. Such speeds are reasonable given that observations in the upwelling area showed a meridional southward transport of up to $1.4 \mathrm{~m} / \mathrm{s}$ at $12^{\circ} 40^{\prime} \mathrm{N}$ at a water depth of $80-120 \mathrm{~m}$ (Dippner et al. 2007), which covers the MSW located in a water depth of 70-140 m.

Five different time series, the MEI, the Niño3.4 index, the PDO index, the TPDV index, and the EMI (Fig. 4), were lag correlated with the monthly mean MSW salinity. Only a weak correlation exists between PDO index and monthly mean MSW salinity. EMI and mean MSW salinity are uncorrelated. The correlation between mean MSW salinity and monthly MEI values was highest with a lag of two months $(r=0.99, p<0.001, N=6)$, though a lag of 3 months was also significant with respect to the $99 \%$ confidence level (Fig. 4). A significant longer lasting correlation between MEI, Niño3.4 index, TPDV index, and mean MSW salinity can be identified, which persists nearly half a year. This finding is consistent with the results of $\mathrm{Qu}$ et al. (2004) and of Gordon et al. (2012) who documented that LST is the key process conveying the impact of ENSO
Fig. 7 Mean surface velocity fields for the SW monsoon onset in early summer (MJJ) 2016

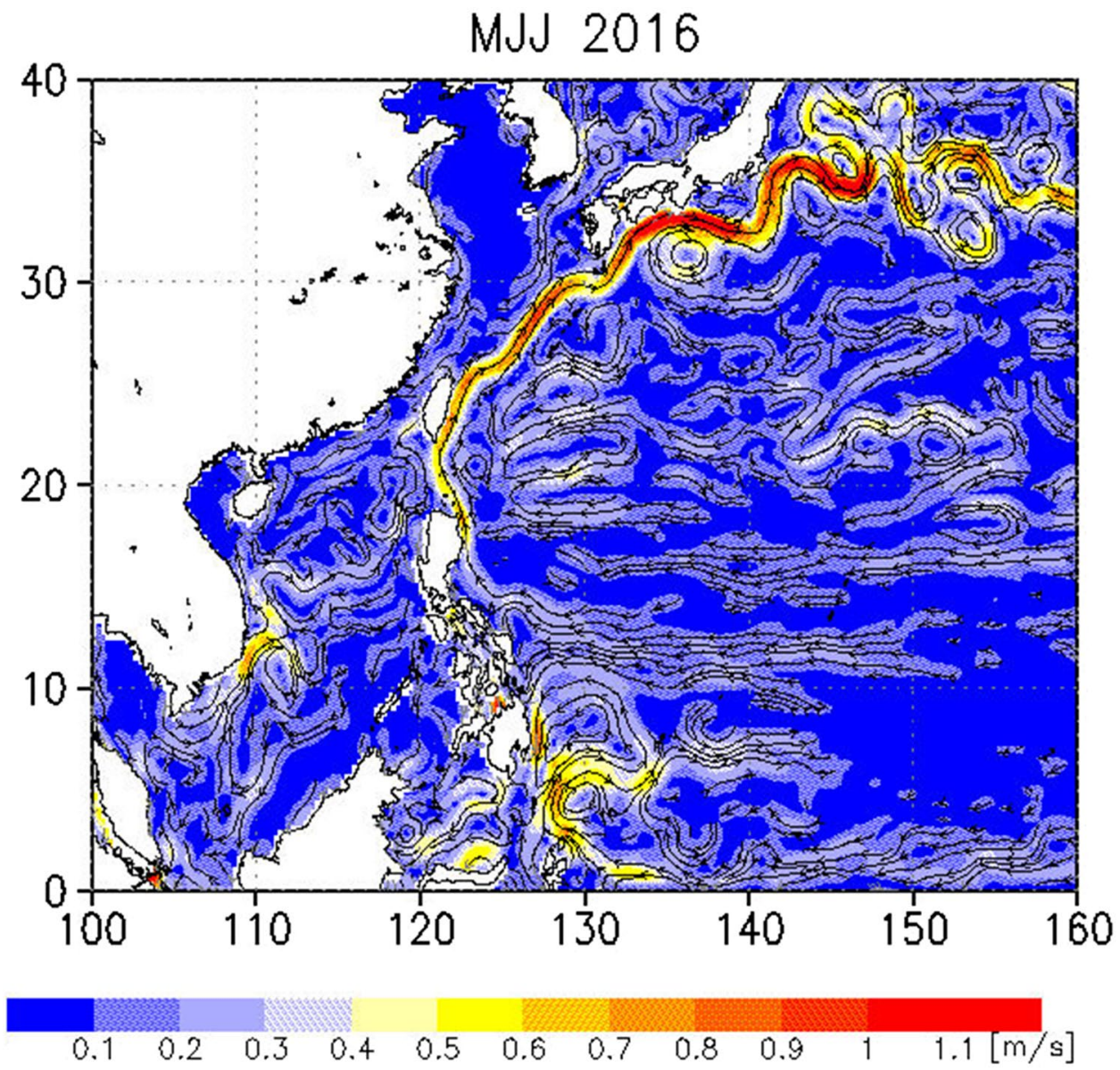



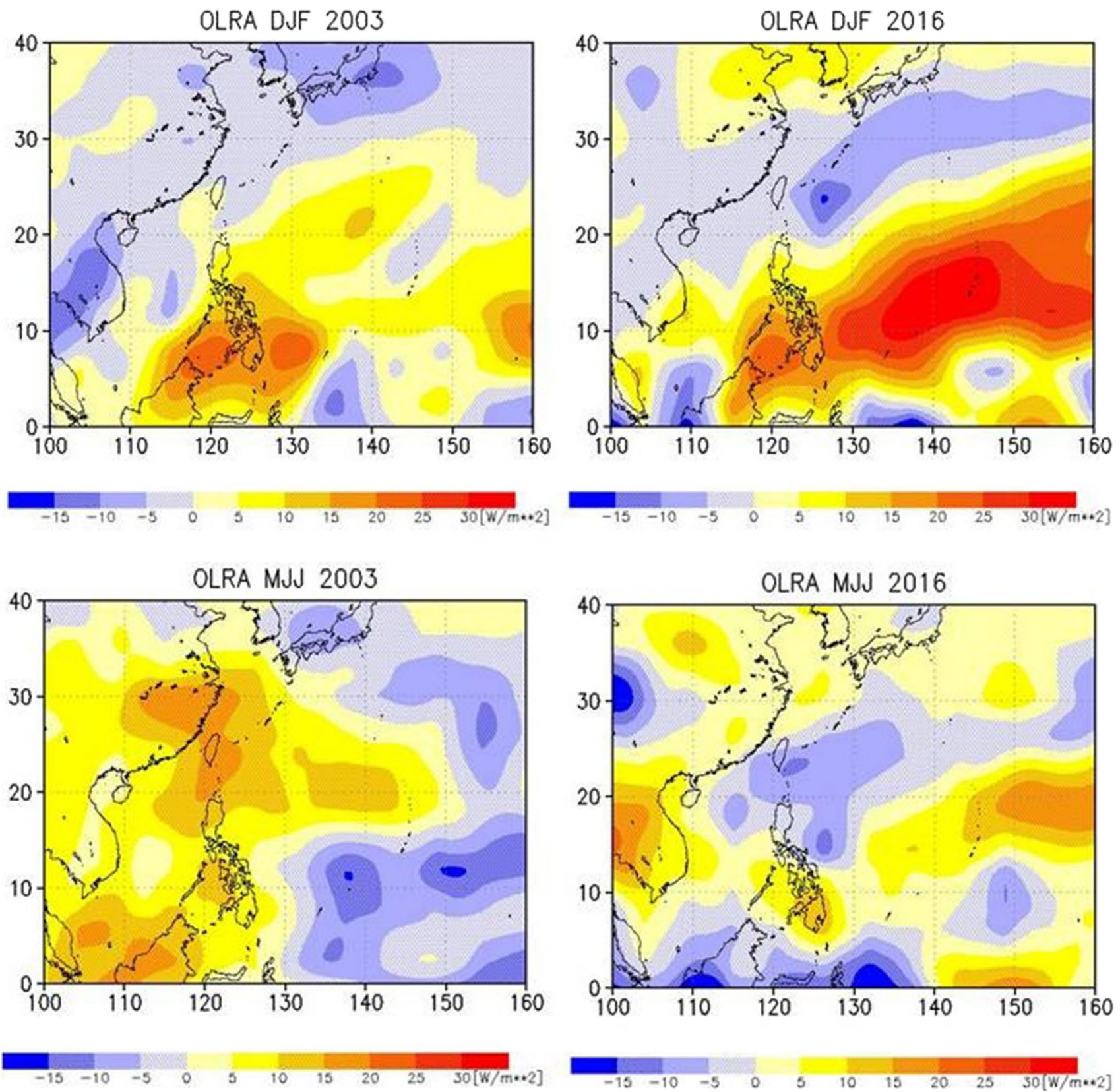

Fig. 8 Mean OLR anomalies for winter (DJF) 2003 and 2016 (upper panel) and for the SW monsoon onset in early summer (MJJ) 2003 and 2016 (lower panel)

to the SCS. In other words, the inflow into SCS is mainly driven by the variability in the north-western tropic Pacific Ocean.

The EAWMI, the ENSO-related part of EAWMI, and the residuum are displayed in Fig. 5. EAWMI is significantly correlated to the winter MEI $(r=0.68, p<0.01, N=68)$. The explained variance of the ENSO-related part and the ENSO-unrelated part is $53 \%$ and $47 \%$, respectively. The ENSO-unrelated part is significantly correlated to the winter PDO $(r=-0.36, p<0.05, N=68)$, which suggests that both climate modes contribute equally to the variability of EAM during winter.

The composites (Figs. S2 and S3) show weak gradients in GPH anomalies for the PDO + and PDO- pattern indicating no pronounced contribution of PDO to the atmospheric circulation during either the winter or summer monsoons.

If ENSO is included in the SWM composites, all patterns are very similar in the ENSO + case (Fig. 6). The position of the western Pacific tropical high is nearly the same, but the gradients are different. The highest gradients in GPH 

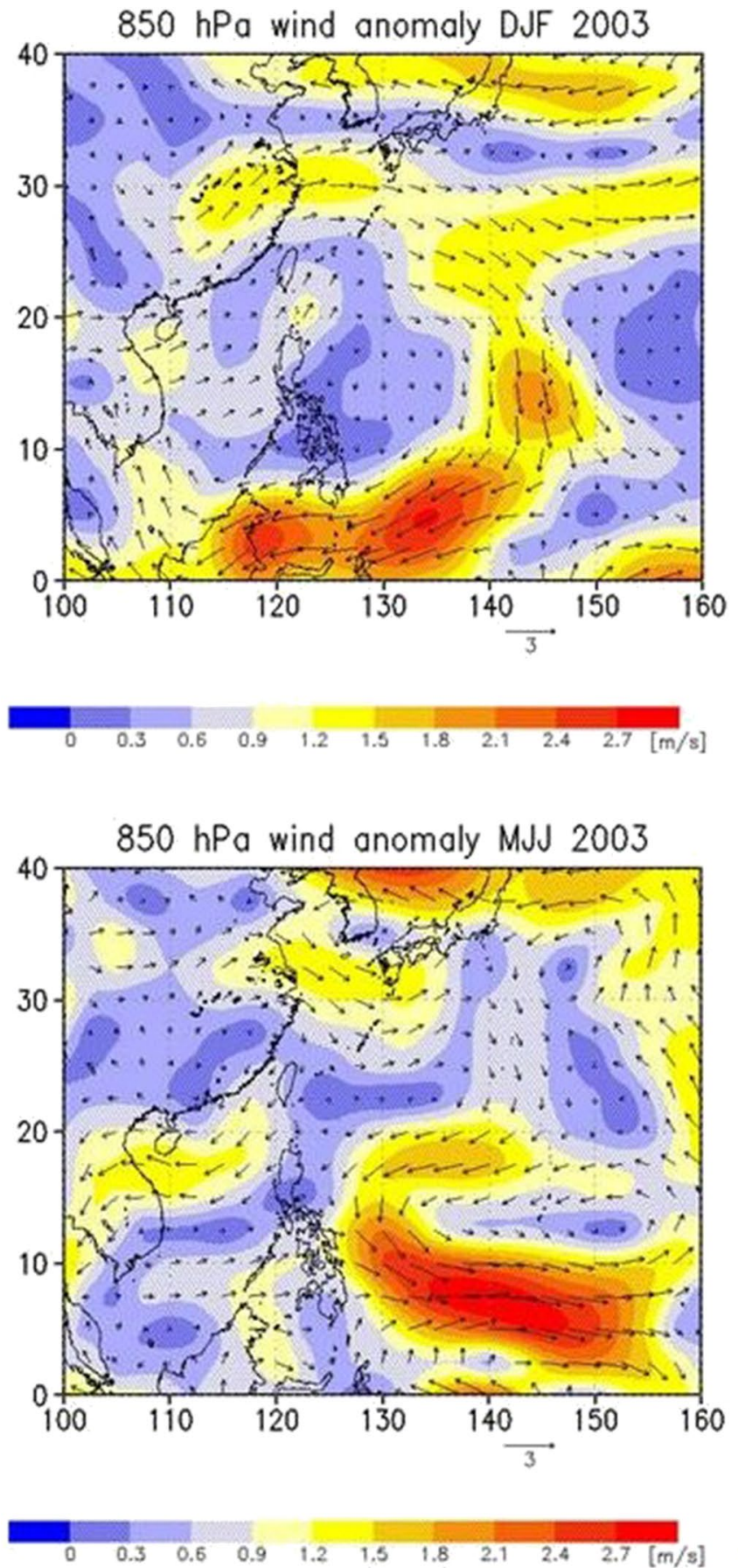
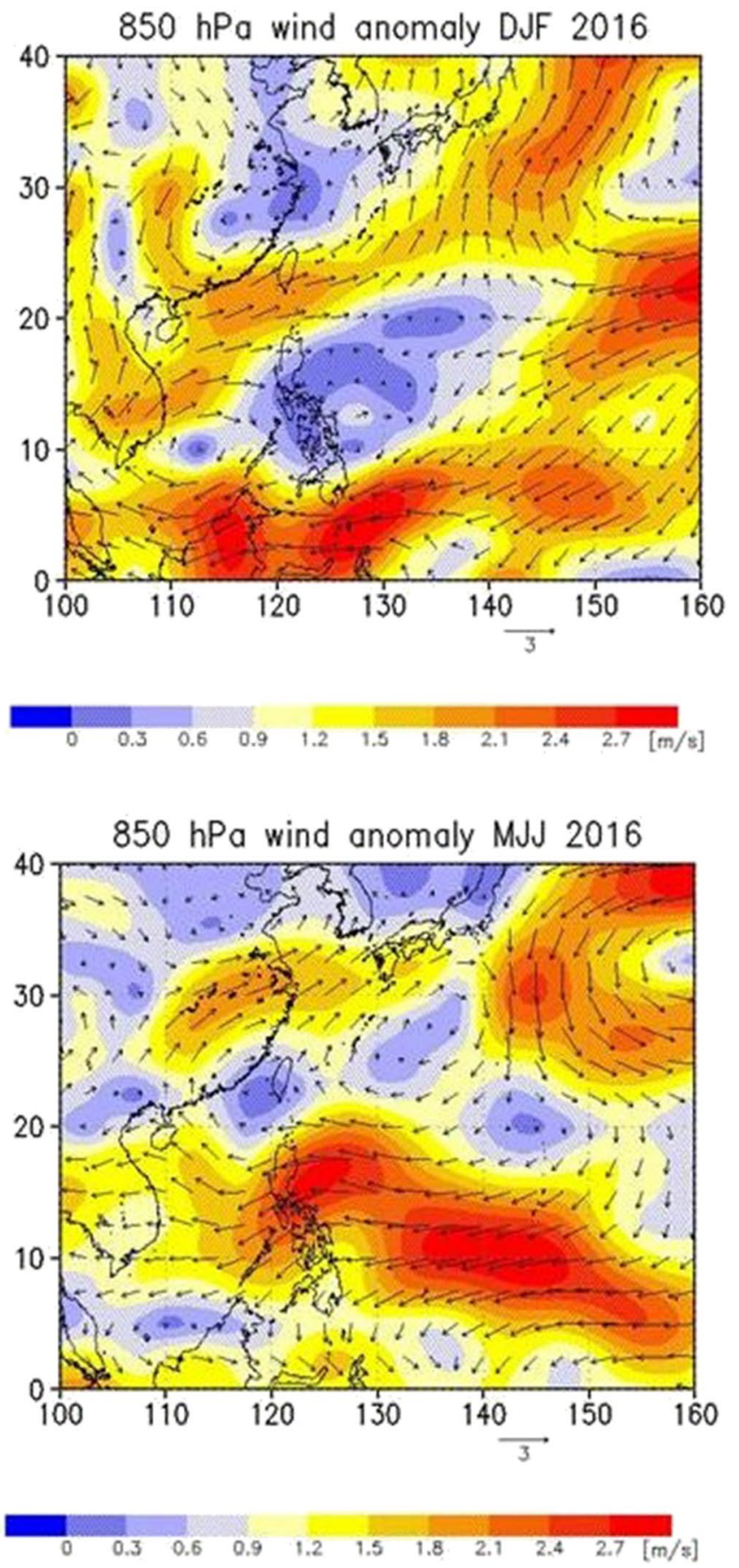

Fig. 9 Mean vector wind anomalies at $850 \mathrm{hPa}$ for winter (DJF) 2003 and 2016 (upper panel) and for the SW monsoon onset in early summer (MJJ) 2003 and 2016 (lower panel)

anomalies occur in the (ENSO + PDO-) pattern, a situation similar to 2003, followed by the ENSO + pattern. The weakest gradient appears in the $(\mathrm{ENSO}+\mathrm{PDO}+)$ pattern when ENSO and PDO are in the same phase, e.g., in 2016. The consequence of the similarity in patterns is that the atmospheric forcing of all three patterns causes a northward shift of NEC and the position of the NEC bifurcation latitude. Except the position of the western Pacific tropical high, the pattern during winter monsoon is very similar (Figs. S4 and S6).

The ENSO- and the (ENSO- PDO-) patterns (Figs. S5 and S9) are similar to one other and are characterized by a western Pacific subtropical high located between $30^{\circ} \mathrm{N}-40^{\circ} \mathrm{N}$ and $130^{\circ} \mathrm{E}-150^{\circ} \mathrm{E}$, which overlaps with the 
location of the outcrop zone (Fig. 1; Yan et al. 2013). This atmospheric circulation pattern causes a southward shift of NEC and NEC bifurcation latitude, which drives the Subtropical Counter Current (STCC) at the surface from the outcrop zone into the area of the Luzon Strait.

The (ENSO- PDO +) patterns are remarkable (Figs. S7 and S9). During summer, a large persistent trough south of China prevents inflow into the SCS. During winter, the $(\mathrm{ENSO}-\mathrm{PDO}+)$ pattern is a particularly striking composite as it shows that a large trough is formed west of the Philippines. This atmospheric forcing causes transport of WNPCW in southwest direction to the Luzon Strait. However, this pattern occurred only five times during the last century (Gershunov and Barnett 1998).

The geostrophic surface velocities (Fig. 7 and Figs. S10-S12 in SI) generally show similar patterns to one another with few specific but essential differences. In all figures, a meandering strong Kuroshio is visible and during winter time, a strong NECC. During early summer, NECC is pronounced in 2003 but weak in 2016. NEC and the NEC bifurcation show different positions. During winter 2003, NEC is located between $15^{\circ} \mathrm{N}$ and $16.2^{\circ} \mathrm{N}$, in winter 2016 between $16.5^{\circ} \mathrm{N}$ and $17.8^{\circ} \mathrm{N}$, in early summer 2003 around $15^{\circ} \mathrm{N}$, and in early summer 2016 between $12.5^{\circ} \mathrm{N}$ and $13.8^{\circ} \mathrm{N}$. This indicates that after the SWM onset in 2016, the Kuroshio transports NPEW to the north. In all patterns except early summer 2016, the Kuroshio water is mixed eastward of the Strait of Luzon with WNPCW, which is transported by STCC. In all cases, a mixture of NPEW and WNPCW is the source of LST and hence MSW, but in early summer 2016, only NPEW is transported into the SCS.

A further exciting aspect of our observations is that both 2003 and 2016 were post-ENSO + years, but with different PDO polarity: a negative PDO polarity in 2003 (Nan et al. 2016) and a positive PDO polarity in 2016 (Zeng et al. 2016). Furthermore, in 2003, an El Niño Modoki occurred in the central Pacific (Lee and McPhaden 2010) whereas in 2016, the canonical Eastern-Pacific El Niño occurred (Fig. S13).

Further comparison of 2003 and 2016 shows that the dominant atmospheric driver is the variability in outgoing long-wave radiation (OLR) and in zonal wind in the tropics. During winter in both years, the OLR anomalies were positive but $\sim 35 \mathrm{~W} / \mathrm{m}^{2}$ higher in 2016 (Fig. 8). The negative anomaly of OLR during early summer 2003 south of $15^{\circ} \mathrm{N}$ in the WTP indicates strong convection. During early summer 2016, the OLR anomalies were positive in the WTP.

The corresponding $850 \mathrm{hPa}$ vector wind anomalies (Fig. 9) show patchy patterns especially during early summer. In 2003, west of the Philippines and south of $15^{\circ} \mathrm{N}$, strong westerly vector wind anomalies at $850 \mathrm{hPa}$ occur as a response to the strong convection. The easterly wind anomaly north of $15^{\circ} \mathrm{N}$ causes a rather heterogeneous flow field in the geostrophic surface velocity. In contrast, the $850 \mathrm{hPa}$ vector wind anomalies in early summer 2016 show a pronounced easterly component reaching from the equator at $160^{\circ} \mathrm{E}$ to $20^{\circ} \mathrm{N}$ close to the Strait of Luzon. This local wind field drives the NEC and the Kuroshio and transports NPEW to the north, feeding the LST.

\section{Discussion}

The dominant modes of inter-decadal and inter-annual variability in the North Pacific Ocean are the PDO (Mantua 2001) and the ENSO (Philander 1990), which influence the SST, SLP, and surface winds in a similar way. ENSO is the most energetic climate signal in the tropical Pacific with period of approximately 3-5 years (Philander 1990). In contrast, PDO can persist 20-30 years (Latif and Barnett 1994; Mantua 2001; Tourre et al. 2005). Mantua et al. (1997) also pointed out that the response of Pacific climate to ENSO and PDO is stronger in the tropics and weaker in the mid-latitudes.

A decomposition of the constructed EAWMI into its ENSO-related and ENSO-unrelated parts suggests that EAWMI is driven by both ENSO and PDO. The EAWMI is similar to the index constructed by Huang et al. (2003) who showed that the EAM was stronger from the mid-1970s to the late 1980s, but tended to be weaker by the early 1990s, which is consistent with a negative PDO polarity starting in 1993 (Nan et al. 2016; Zeng et al. 2016) and a period of freshening of the LST in the period between 1990 and 2012 (Zeng et al. 2016). The EAWMI is also similar to the winter index constructed by Chen et al. (2000), who showed on a $500 \mathrm{hPa}$ level that EAWMI peaks synchronously with the El Niño events. They also showed that after a strong EAM during winter, the Pacific subtropical high will shift northward in the following summer. In contrast, our results are different to the analysis of Chen et al. (2013), who showed a dominance of the ENSO-unrelated part with an explained variance of $65 \%$ and a smaller contribution of the ENSOrelated part of $35 \%$. The differences in the two analyses are the length of the time series and the size of the considered area, which suggests that the definition of EAWMI and its ENSO relation is very sensitive to the selection of the considered area. Chen et al. (2013) used an area that covers $20^{\circ} \mathrm{N}-40^{\circ} \mathrm{N}$ in meridional direction and excludes a major part of the tropics. It might be that this affects the dominance of the ENSO-unrelated part in the EAWMI.

On a seasonal scale, the EAM and in particular the position of the Inter-Tropical Convergence Zone are the major driving forces of circulation and hydrography in the SCS (Dippner et al. 2013; Chen et al. 2013). One of the strongest response signals is the position and intensity of coastal upwelling off the coast of Vietnam, which in turn influences the pathway of the Mekong River plume 
(Voss et al. 2006), nutrient distributions (Loick et al. 2007; Bombar et al. 2010), phytoplankton species composition (Loick-Wilde et al. 2017; Weber et al. 2019), distributions of harmful algae blooms (Doan-Nhu et al. 2010; Dippner et al. 2011), and the diversity and abundance of diazotrophic microorganisms (Moisander et al. 2008) in the SCS.

The seasonality of the EAM and its inter-annual modulation by ENSO (Zhang 2000) and inter-decadal variation by PDO (Chen et al. 2013) regulates the inflow into the SCS by altering its strength and the relative contributions of WNPCW and NPEW (Tomczak and Godfrey 1994). Under normal climatic conditions, the westward-propagating NEC bifurcates west of the Philippines between $13^{\circ} \mathrm{N}$ and $20^{\circ} \mathrm{N}$ into the northward Kuroshio, which contributes the most to the LST (Nan et al. 2015) and southward Mindanao Current (Qu et al. 2009; Tozuka et al. 2009).

The three composites ENSO+, $(\mathrm{ENSO}+\mathrm{PDO}+)$, and $(\mathrm{ENSO}+\mathrm{PDO}-)$ during SWM suggest that the pattern itself is forced by ENSO and the intensity is modulated by PDO (Fig. 6). All three patterns cause a northward shift of the NEC and the position of the NEC bifurcation latitude (red arrow in Fig. 1), which is a necessary prerequisite for the intrusion of NPEW into the SCS. When ENSO and PDO are in a positive phase, the Kuroshio is much weaker after the NEC bifurcation. The consequence is that the meridional advection of potential vorticity is not strong enough to overcome the $\beta$-effect, allowing the Kuroshio to transport more NPEW through the Luzon Strait, the so-called teapot effect (Sheremet 2001). Model simulations indicate that the LST would be greatly reduced without the $\beta$-effect (Yuan 2002).

The ENSO + and the (ENSO + PDO +) patterns as well as the ENSO- and the (ENSO- PDO-) patterns are very similar during winter and summer monsoon (Figs. S4-S9). This is in good agreement with the results of Mantua(2001) and Delcroix et al. (2007) who demonstrated that both climate modes show remarkable similarities if both modes are in the same positive or negative phase.

All ENSO + composites independent of the PDO phase shift the bifurcation latitude to the north, which is a necessary condition of LST intrusion into the SCS. However, these composites do not explain the difference between 2003 and 2016, two post-ENSO + years with different PDO polarity and why during the 2016 SWM mainly NPEW was transported into the SCS (Fig. 7).

To understand the mechanisms, we investigated the complex multi-time scale processes in the WTP, which is a part of the Indo-Pacific warm pool, the largest area of warm surface water in the world ocean. This region is characterized by a SST exceeding $28{ }^{\circ} \mathrm{C}$, weak trade winds, and atmospheric deep convection (Kidwell et al. 2017; Weller et al. 2016). WTP can be classified by different properties such as centroid movement, length, depth, heat content, and volume
(Kidwell et al. 2017), which are correlated to all equatorial climate indices and the PDO.

The influence of zonal winds and OLR anomalies close to the equator, the essential variables for the MJO, contributes to more than $55 \%$ of the atmospheric variability over the tropics (Kessler 2001; Roxy et al. 2019). This aspect of potential forcing on the LST intrusion dynamics has not been considered as far as we know. In 2003, a strong convection (negative OLR anomalies, Fig. 8) occurred during the SWM onset in early summer. When the convection is strong, the convergence of flow is intensified in the lower troposphere and a cyclonic circulation will be intensified over the WTP (Fig. 9; Huang et al. 2001). In 2016, the convection in early summer was weak over the WTP (Fig. 8). This will in turn intensify an anticyclonic circulation over the WTP (Fig. 9), which transports the NPEW into the SCS (Fig. 7). These findings are consistent with the results of Huang et al. (2003) who showed that the convective activity over the WTP warm pool has a significant impact of the zonal shift of the western Pacific subtropical high. If the convection is strong over the warm pool, the western Pacific subtropical high shifts eastwards, whereas it extends westward if the convective activities are weaker over the warm pool. These results are also consistent with the MJO variability in the WTP (Figs. S14 and S15 in SI) as seen in the MJO index of Wheeler and Hendon (2004) for these years.

Summing up these findings, we can conclude that the increase in the salinity of MSW in the SCS in 2016 was a result of multi-time scale processes. The inter-annual variability of LST is dynamically related to the Kuroshio and the NEC bifurcation latitude (Wang et al. 2006), which is regulated by ENSO. When ENSO and PDO are in a positive phase, the Kuroshio is much weaker after the NEC bifurcation, which is a favorable condition for strong inflow (Sheremet 2001). In addition, in 2016, convective activity was weak over the WTP and an anticyclonic circulation was intensified, which transported the saltier NPEW into the SCS. The last aspect indicates a good relationship, but a complex interaction between SST, convection, and circulation over the WTP warm pool.

Previous studies investigating the variability of the LST (Wang et al. 2006; Yu and Qu 2013) neglected the influence of OLR and considered only the wind stress over the whole equatorial Pacific. In addition, Wang et al. (2006) and $\mathrm{Yu}$ and $\mathrm{Qu}$ (2013) used annual mean wind stress for applying the Island Rule to the LST variability. Our analysis shows that the time for the optimal inflow conditions of LST is the onset of SWM in May. In this case, annual mean wind stress is not helpful in understanding the multi-time scale dynamics of WTP. Furthermore, the application of the Island Rule is questionable. The Island Rule was developed by Godfrey (1989) for a steady-state ocean and ideal fluid only. The effects of friction and non-linear processes were 
excluded from the calculation. Considering the narrowness and the shallowness of the Strait of Luzon, friction cannot be neglected. The application of Island Rule (Wang et al. 2006; Yu and Qu 2013) might yield qualitative estimates of LST but cannot explain the transport of NPEW into the SCS.

Is the increase in MSW salinity a transient phenomenon? To investigate this aspect, we searched for periods with conditions similar to those in 2016. An inspection of the NCEP/NCAR reanalysis data (Kalnay et al. 1996) showed that only one record exists that fulfils the criteria of a postENSO + year with positive PDO phase and weak MJO during the SWM onset. The year 1983 is characterized by positive anomalies in OLR and easterly winds in the WTP (not shown), which were similar to the atmospheric conditions in 2016. However, we cannot show that in this year, MSW has a higher salinity than normal. The reason is that no observations are available because in situ observations in SCS were sparse and infrequent before the Vietnamese-German cruises, which started in 2003. In addition, we cannot show that during the 1983 SWM NEC transported NPEW into the SCS, because no geostrophic velocities from satellite were available since the observation program started in 1993 (QUID 2018). We can identify similar atmospheric conditions in the past as in 2016, but we cannot show the response of the WTP and SCS to this forcing. The consequence is that we cannot answer questions on the transience of this phenomenon.

Is the increase in MSW salinity related to global warming? During the last decades, various observations indicated major changes in the Pacific Ocean especially in the WTP. From 1980 to 2010, the increasing intensity and the occurrence frequency of El Niño Modoki events in the central Pacific almost doubled (Lee and McPhaden 2010). Model inter-comparison indicated that the occurrence ratio of El Niño Modoki to the canonical El Niño is projected to increase as much as five times under global warming (Yeh et al 2009). The change is related to a flattening of the thermocline in the equatorial Pacific. Weller et al. (2016) address the observed increase in intensity and frequency to greenhouse gas forcing. Observed Indo-Pacific sea level pressure reveals a weakening of the Walker circulation, which has altered the thermal structure and circulation of the tropical Pacific (Vecchi et al. 2006). Model simulations indicate that this trend is related to anthropogenic forcing (Vecchi et al. 2006). A reconstruction of MJO over 1905-2008 using tropical surface pressure showed a $13 \%$ increase per century in MJO amplitude (Oliver and Thompson, 2012). For the period 1981-2018, the rapid warming over the tropical oceans has warped the MJO life cycle with increasing residence time over the Indo-Pacific maritime continent of 5-6 days. These changes in MJO life cycle were
Table 3 Modified definitions of characteristic SCS water masses originally given in Dippner and Loick-Wilde (2011): deep water (DW), permanent thermocline water (PTW), maximum salinity water (MSW), open sea water (OSW), Mekong/Gulf of Thailand Water (MKGTW), water mass 1 (WM1): mixed water between MSW and PTW, WM2: mixed water between MSW and OSW, WM3: mixed water between OSW and MKGTW, and WM4: mixed water between OSW, MKGTW, and MSW. Adjusted values are in bold, previous values in parentheses

\begin{tabular}{|c|c|c|}
\hline Water mass & Temperature $\left({ }^{\circ} \mathrm{C}\right)$ & Salinity \\
\hline DW & $<2.5$ & $>34.6$ \\
\hline PTW & 8.5-10.5 (7-9) & $34.4-34.5$ \\
\hline MSW & 17-22 (17-19) & $\mathbf{3 4 . 2 - 3 4 . 8}(>34.3)$ \\
\hline OSW & $26-31.5(26-31)$ & $33.7-\mathbf{3 4 . 2}(33.7-34.1)$ \\
\hline MKGTW & 27-31.5 (27-31) & $<32.9$ \\
\hline WM1 & 10.5-17 (9-17) & $\mathbf{3 4 . 2 - 3 4 . 8}(34-35)$ \\
\hline WM2 & 22-28 (19-28) & $\mathbf{3 4 . 2 - 3 4 . 8}(34.1-34.6)$ \\
\hline WM3 & 26-31.5 (26-31) & $32.9-33.7$ \\
\hline WM4 & $22-26$ & $33.3-\mathbf{3 4 . 2}(33.3-34.1)$ \\
\hline
\end{tabular}

associated with an expansion to the Indo-Pacific warm pool (Roxy et al. 2019). All of these changes in the last decades might indicate the consequences of global warming. The increase in the salinity of MSW in the SCS may be a small overseen piece of puzzle in this context and should be the subject of further observations.

The MSW sampled in summer 2016 had a significantly higher salinity compared to previous years, which resulted from a particularly strong El Niño during the winter of 2015/2016. This salinity shift in MSW necessitates a modification of the water mass definition given by Dippner and Loick-Wilde (2011); the changes to which are displayed in Table 3. Note that WM1 to WM4 are not characteristic water masses in the classical definition of Helland-Hansen (1916); however, an introduction of these mixed water masses is meaningful for various reasons. Firstly, the temperature and salinity ranges of the water masses defined by Rojana-anawat et al. (2001) are too coarse to define "end members" of mixing. Secondly, although characteristic water mass analysis is a useful tool in understanding mixing dynamics of water masses (Wüst 1936), the mixing between MSW and OSW is difficult to interpret because of a clear bifurcation in the mixing diagram (Dippner et al. 2007). Thirdly, all water masses are different in their biogeochemical and phytoplankton species compositions (Loick-Wilde et al. 2017), which justify the introduction of mixed water masses or alternatively the habitat type concept (Weber et al. 2019). Our modified definition of characteristic water masses may be useful for oceanographers and biologists operating in the SCS.

Supplementary Information The online version contains supplementary material available at https://doi.org/10.1007/s10236-021-01481-w. 
Acknowledgements The authors are indebted to Schmidt Ocean Institute for the ship time and the captain and crew of "RV Falkor" for their support and hospitality (Cruise FK160603). Sarah Weber has received support by the Deutsche Forschungsgemeinschaft under the DFG grant VO 487/13-1. Special thanks to Benjamin Ramcharitar for processing the satellite data. The topography of the South China Sea and adjacent areas was provided by Delft Hydraulics, which is greatly acknowledged. NCEP reanalysis data provided by the NOAA/OAR/ESRL PSD, Boulder, CO, USA, from their Web site at https://www.esrl.noaa.gov/ psd/. This study has been conducted using E.U. Copernicus Marine Service Information.

Funding Open Access funding enabled and organized by Projekt DEAL.

Open Access This article is licensed under a Creative Commons Attribution 4.0 International License, which permits use, sharing, adaptation, distribution and reproduction in any medium or format, as long as you give appropriate credit to the original author(s) and the source, provide a link to the Creative Commons licence, and indicate if changes were made. The images or other third party material in this article are included in the article's Creative Commons licence, unless indicated otherwise in a credit line to the material. If material is not included in the article's Creative Commons licence and your intended use is not permitted by statutory regulation or exceeds the permitted use, you will need to obtain permission directly from the copyright holder. To view a copy of this licence, visit http://creativecommons.org/licenses/by/4.0/.

\section{References}

Arbic BK, Scott RB, Chelton DB, Richman JG, Shriver JF (2012) Effects on stencil width on surface ocean geostrophic velocity and vorticity estimation from gridded satellite altimeter data. J Geophys Res 117:C03029. https://doi.org/10.1029/2011/JC007367

Ashok K, Behera SK, Rao SA, Weng H, Yamagata T (2007) El Nino Modoki and its possible teleconnection. J Geophy Res 112(C11007):1-27

Barnett TP, Pierce DW, Latif M, Dommenget D, Saravanan R (1999) Interdecadal interactions between the tropics and midlatitude in the Pacific basin. Geophys Res Lett 26(5):615-618

Bjerknes J (1969) Atmospheric teleconnections from the equatorial Pacific. Mon Weather Rev 97(3):163-172

Bombar D, Dippner JW, Hai ND, Lam NN, Liskow I, Loick-Wilde N, Voss M (2010) Sources of new nitrogen in the Vietnamese upwelling region of the South China Sea. J Geophys Res 115:C06018. https://doi.org/10.1029/2008/JC005154

Chan JCL, Zhou W (2005) PDO, ENSO, and the early summer monsoon rainfall over south China. Geophys Res Lett 32:L09910

Chao SY, Shaw PT, Wu SY (1996) El Niño modulation of the South China Sea circulation. Progr Oceanogr 38:51-93

Chen TC, Chen JR (1995) An observational study of the South China Sea monsoon during the 1979 summer-onset and life-cycle. Mon Weather Rev 123:2295-2318

Chen W, Graf HF, Huang R (2000) The interannual variability of East Asian Winter Monsoon and its relation to the summer monsoon. Adv Atmos Sci 17(1):48-60

Chen W, Feng J, Wu R (2013) Roles of ENSO and PDO in the link of the East Asian Winter Monsoon to the following Summer Monsoon. J Climate 26:622-635

Chu P, Li R (2000) South China Sea isopycnal-surface circulation. J Phys Oceanogr 30:2419-2438

Dale WL (1956) Wind and drift current in the South China Sea. Malay J Trop Geogr 8:1-31
Delcroix T, Cravette S, McPhadan MJ (2007) Decadal variations and trends in tropical Pacific sea surface salinity since 1970. J Geophys Res 112:C03012. https://doi.org/10.1029/2006JC003801

Dippner JW, Loick-Wilde N (2011) A redefinition of water masses in the Vietnamese upwelling area. J Mar Syst 84:42-47

Dippner JW, Nguyen KV, Hein H, Ohde T, Loick N (2007) Monsoon induced upwelling off the Vietnamese coast. Ocean Dyn 57:46-62

Dippner JW, Nguyen NL, Doan-Nhu H, Subramaniam A (2011) A model for the prediction of harmful algae blooms in the Vietnamese upwelling area. Harmful Algae 10:606-611

Dippner JW, Bombar D, Loick-Wilde N, Voss M, Subramaniam A (2013) Comment on "Current separation and upwelling over the southeast shelf of Vietnam in the South China Sea" by Chen, et al (2013). J Geophys Res Oceans 118:1618-1623

Doan-Nhu H, Nguyen-Ngoc L, Dippner JW (2010) Development of phaeocystis globosa blooms in the upwelling water of the South Central Coast of Viet Nam. J Mar Syst 83:253-261

Gershunov A, Barnett TP (1998) Interdecadal modulation of ENSO teleconnections. Bull Am Met Soc 79(2):2715-2725

Godfrey JS (1989) A Sverdrup model of the depth-integrated flow for the world ocean allowing for island circulation. Geophys Astrophys Fluid Dynamics 47:89-112

Gordon AL, Huber BA, Metzger EJ, Dwi Susanto R, Hurlburt HE, Rameyo Adi T (2012) South China Sea throughflow impact on Indonesian throughflow. Geophys Res Lett 39:L11602. https:// doi.org/10.1029/2012GL052021

Hare SR, Mantua NJ (2000) Empirical evidence for North Pacific regime shifts in 1977 and 1989. Prog Oceanogr 47(2-4):103-146

Helland-Hansen B (1916) Nogen hydrografiske metoder. Scand. Naturforsk. Möte, Kristiania.

Hu D, Wu L, Cai W, Gupta AS, Ganachaud A, Qiu B, Gordon AL, Lin X, Chen Z, Hu S, Wang G, Wang Q, Springtall J, Qu T, Kashino Y, Wang F, Kessler WS (2015) Pacific western boundary currents and their role in climate. Nature 522:299-308

Hu J, Kawamura H, Hong H, Qi Y (2000) A review on the currents in the South China Sea: seasonal circulation, South China Sea warm current and Kuroshio intrusion. J Oceanogr 56(6):607-624 CL 85

Hu S, Hu D, Guan C, Xing N, Li J (2017) Variability of the western Pacific warm pool structure associated with El Niño. Clim Dyn 49:2431-2449

Huang R, Zhang R, Yan B (2001) Dynamical effect of the zonal wind anomalies over the tropical western Pacific on ENSO cycles. Science in China (d) 44(12):1089-1098

Huang R, Zhou L, Chen W (2003) The progress of recent studies on the variability of the East Asian Monsoon and their causes. Adv Atmos Sci 20(1):55-69

Kalnay E et al (1996) The NCEP/NCAR Reanalysis 40-year Project. Bull Am Met Soc 77:437-471

Kashino Y, Atmadipoera A, Kuroda Y, Lukijanto, (2013) Observed features of the Halmahera and Mindanao Eddies. J Geophys Res Oceans 118:6543-6560

Kessler WS (2001) EOF representations of the Madden-Julian oscillation and its connection with ENSO. J Climate 14:3055-3061

Kidwell A, Han L, Jo YH, Yan XH (2017) Decadal western Pacific warm pool variability: a centroid and heat content study. Sci Rep 7:13141

Kim YY, Qu T, Jensen T, Miyama T, Mitsudera H, Kang HW, Ishida A (2004) Seasonal and interannual variations of the North Equatorial Current bifurcation in a high-resolution OGCM. J Geophys Res 109:C03040

Lagerloef GSE, Mitchum G, Lucas R, Niiler P (1999) Tropical Pacific currents estimated from altimeter, wind and drifter data. J Geophys Res 104(23):23313-23326

Latif M, Barnett TP (1994) Causes of decadal climate variability over the North Pacific and Borth America. Science 266:634-637 
Lee T, McPhaden J (2010) Increasing intensity of El Nino in the central-equatorial Pacific. Geophys Res Lett 37:L14603

Loick N, Dippner JW, Hai ND, Liskow I, Voss M (2007) Pelagic nitrogen dynamics in the Vietnamese upwelling area. Deep Sea Res I 54:596-607. https://doi.org/10.1016/j.dsr.2006.12.009

Loick-Wilde N, Bombar D, Doan-Nhu H, Nguyen LN, Nguyen-Thi AM, Voss M, Dippner JW (2017) Microplankton biomass and diversity in the Vietnamese upwelling area during SW monsoon under normal conditions and after an ENSO event. Prog Oceanogr 153:1-15

Liu KK, Chao SY, Shaw PT, Gong GC, Chen CC, Tang TY (2002) Monsoon-forced chlorophyll distribution and primary production in the South China Sea: observations, and numerical study. Deep Sea Res I 49:1387-1412

Madden RA, Julian PR (1972) Description of global-scale circulation cells in the tropics with a $40-50$ day period. J Atmos Sci 29:1109-1123

Madden RA, Julian PR (1994) Observations of the 40-50 day oscillation - a review. Mon Weather Rev 122:814-837

Mantua NJ (2001) The Pacific Decadal Oscillation. In: Encyclopedia of global environmental change, John Wiley \& Sons, Inc.

Mantua N, Hare S (2002) The Pacific Decadal Oscillation. J Oceanogr 58:35-44

Mantua NJ, Hare SR, Zhang Y, Wallace JM, Francis RC (1997) A Pacific inter-decadal climate oscillation with impact on salmon production. Bull Am Met Soc 78:1069-1079

Metzger EJ, Hurlburt HE (1996) Coupled dynamics of the South China Sea, the Sulu Sea, and the Pacific Ocean. J Geophys Res 101:12331-12352

Moisander PH, Beinart RA, Voss M, Zehr JP (2008) Diversity and abundance of the diazotrophic microorganisms in the South China Sea during intermonsoon. ISME J 2:954-967

Nan F, Xue H, Yu F (2015) Kuroshio intrusion into the South China Sea: a review. Prog Oceanogr 137:314-333

Nan F, Yu F, Xue H, Zeng L, Wang D, Yang S, Nguyen KC (2016) Freshening of the upper ocean in the South China Sea since the early 1990s. Deep Sea Res I 118:20-29

Oliver ECJ, Thompson KR (2012) A reconstruction of Madden-Julian Oscillation variability from 1905 to 2008 . J Clim 25:1996-2019

Philander SGH (1990) El Niño, La Niña and the Southern Oscillation. Elsevier, New York, 289 pp.

Pohlmann T (1987) A three-dimensional circulation model of the South China Sea. In: Nihoul JJ, Jamart B (eds) Threedimensional models of marine and estuarine dynamics. Elsevier, New York, pp 245-268

Pujol MI, Faugere Y, Taburete G, Dupuy S, Pelloquin C, AblainM PN (2016) DUACS ST2014: the new multi-mission altimeter data set reprocessed over 20 years. Ocean Sci 12:1067-1090. https://doi. org/10.5194/os-12-1067-2016

Qu T, Mitsudera H, Yamagata T (1999) A climatology of the circulation and water mass distribution near the Philippine coast. J Phys Oceanogr 29:1488-1505

Qu T, Mitsudera H, Yamagata T (2000) Intrusion of the North Pacific waters into the South China Sea. J Geophys Res 105(C3):6415-6424

Qu TD, Kim YY, Yaremchuk M, Tozuka T, Ishida A, Yamagata T (2004) Can Luzon Strait transport play a role in conveying the impact of ENSO to the South China Sea? J Climate 17:3644-3657

Qu T, Du Y, Meyers G, Ishida A, Wand D (2005) Connecting the tropical Pacific with Indian Ocean through South China Sea. Geophys Res Lett 32:L2409

Qu T, Du Y, Sasaki H (2006) South China Sea throughflow: a heat and freshwater conveyor. Geophys Res Lett 33:L23617

Qu T, Song YT, Yamagata T (2009) An introduction to the South China Sea throughflow: its dynamics, variability and application for climate. Dyn Atmos Oceans 47:3-14
QUID (2018) Quality information Document for Sea Level TAC DUACS products EU Copernicus Marine Environment Monitoring Service, 66 p. Available at http://marine.copernicus.eu/docum ents/QUID/CMEMS-SL-QUID-008-032-051.pdf

Rayner NA, Parker DE, Horton EB, Folland CK, Alexander LV, Rowell DP, Kent EC, Kaplan A (2003) Global analyses of sea surface temperature, sea ice, and night marine air temperature since the late nineteenth century. J Geophys Res 108(D14):4407. https:// doi.org/10.1029/2002JD002670

Rojana-anawat P, Pradit S, Sukramongkol N, Siriraksophon S (2001) Temperature, salinity, dissolved oxygen and water masses of Vietnamese waters. Proceedings of the SEAFDEC Seminar on Fisheries Resources in the South China Sea, Area 4: Vietnamese Waters, 346-355

Roxy MK, Dasgupta P, McPhaden MJ, Suematsu T, Zhang C, Kim D (2019) Twofold expansion of the Indo-Pacific warm pool wraps the MJO life cycle. Nature 574:647-651

Sheremet VA (2001) Hysteresis of a western boundary current leaping across a gap. J Phys Oceanog 31:1247-1259

Siedler G (1970) Über die Fluktuation der Wasserschichtung im Meer. In: Dietrich G. (Ed.) Erforschung des Meeres, Frankfurt, 53-64.

Tomczak M, Godfrey JS (1994) Regional oceanography: an introduction. Pergamon, 442 pp.

Torrence C, Webster PJ (1999) Interdecadal change in the ENSOmonsoon system. J Climate 12:2679-2690

Tourre YM, Rajagopalan B, Kushnir Y, Barlow M, White WB (2001) Patterns of coherent ocean decadal and interdecadal signals in the Pacific basin during the $20^{\text {th }}$ century. Geophys Res Lett 28:2069-2072

Tourre YM, Cibot C, Terray L, White WB, Dewitte B (2005) Quasidecadal and interdecadal climate fluctuations in the Pacific Ocean from a CGCM. Geophys Res Lett 32:L07710

Tozuka T, Qu T, Masumoto Y, Yamagata T (2009) Impacts of the South China Sea throughflow on seasonal and interannual variations of the Indonesian throughflow. Dyn Atmos Oceans 47:73-85

Vecchi GA, Soden BJ, Wittenberg AT, Held IM, Leetmaa A, Harrison MJ (2006) Weakening of the tropical Pacific atmospheric circulation due to anthropogenic forcing. Nature 441:73-76

Voss M, Bombar D, Loick N, Dippner JW (2006) Riverine influence on nitrogen fixation in the upwelling region off Vietnam. South China Sea Geophys Res Lett 33:L07604

Wang B, Fan Z (1999) Choice of South Asian summer monsoon indices. Bull Am Met Soc 80(4):629-638

Wang B, Ho L, Zhang Y, Lu MM (2004) Definition of South China Sea monsoon onset and commencement of the East Asia summer monsoon. J Climate 17:699-710

Wang B, Huang F, Wu Z, Yang J, Fu X, Kikuchi K (2009) Multi-scale climate variability of the South China Sea monsoon: a review. Dyn Atmos Oceans 47:15-37

Wang D, Liu Q, Huang RX, Du Y, Qu T (2006) Interannual variability of the South China Sea throughflow inferred from wind data and ocean data assimilation products. Geophys Res Lett 33:L14605

Weber SC, Subramaniam A, Montoya JP, Doan-Nhu H, Nguyen-Ngoc L, Dippner JW, Voss M (2019) Habitat delineation in highly variable marine environments. Front Mar Sci 6:112

Weller E, Min SK, Cai W, Zwiers FW, Kim YH, Lee DH (2016) Human-caused Indo-Pacific warm pool expansion. Sci Adv 2(1):e1501719

Wheeler MC, Hendon HH (2004) An all-season real-time multivariate MJO Index: development of an index for monitoring and prediction. Mon Weath Rev 132:1917-1923

Wolter K (1987) The Southern Oscillation in surface circulation and climate over the tropical Atlantic, Eastern Pacific, and Indian Oceans as captured by cluster analysis. J Clim Appl Met 26:540-558 
Wüst G (1936) Die Vertikalschnittes der Temperatur, des Salzgehaltes und der Dichte. Wiss. Ergebn. Dt. Atlant. Exped. „Meteor“ 1925-27, Teil A Atlas 6, Beilage II-XLVI, Berlin.

Wyrtki K (1961) Physical oceanography of the Southeast Asian waters. In: NAGA Report 2 (ed) Scientific results of marine investigations of the South China Sea and Gulf of Thailand 1959-1961, Scripps Institution of Oceanography, University of California, San Diego, La Jolla, CA, p 195

Yan Y, Chassignet EP, Qi Y, Dewar WK (2013) Freshening of surface waters in the northwest Pacific subtropical gyre: observations and dynamics. J Phys Oceanogr 43:2733-2751

Yeh SW, Kug JS, Dewitte B, Kwon MH, Kirtman BP, Jin FF (2009) El Nino in a changing climate. Nature 461:511-514

Yu K, Qu T (2013) Imprint of the Pacific Decadal Oscillation on the South China Sea throughflow variability. J Climate 26(24):9797-9805

Yuan D (2002) A numerical study of the South China sea deep circulation and its relation to the Luzon Strait transport. Acta Oceanol Sinica 21(2):187-202
Zeng L, Liu WT, Xue H, Xiu P, Wang D (2014) Freshening in the South China Sea during 2012 revealed by Aquarius and in situ data. J Geophys Res Oceans 119:8296-8314

Zeng L, Wang D, Xiu P, Shu Y, Wang Q, Chen J (2016) Decadal variation and trends in the subsurface salinity from 1960 to 2012 in the northern South China Sea. Geophys Res Lett 43:12181-12189

Zeng L, Chassignet EP, Schmitt RW, Xu X, Wang D (2018) Salinification in the South China Sea since late 2012: a reversal of freshening since the 1990s. Geophys Res Lett 45:2744-2751

Zhai F, Wang Q, Wang F, Hu D (2014) Decadal variations of Pacific North Equatorial Current bifurcation from multiple ocean products. J Geophys Res Oceans 119:1237-1256

Zhang R (2000) Features of the East Asian monsoon during El Niño Episode. CLIVAR Exchanges 5:21-22 